Article

\title{
Effects of Long-Term Crop-Livestock-Forestry Systems on Soil Erosion and Water Infiltration in a Brazilian Cerrado Site
}

\author{
Jullian Souza Sone ${ }^{1,2, *}$, , Paulo T. Sanches de Oliveira ${ }^{2} \mathbb{D}_{\text {, Pedro A. Pereira Zamboni }}{ }^{2}$, \\ Nelson O. Motta Vieira ${ }^{2}$, Glauber Altrão Carvalho ${ }^{2}$, Manuel C. Motta Macedo ${ }^{3}$, \\ Alexandre Romeiro de Araujo ${ }^{3}$, Denise Baptaglin Montagner ${ }^{3}$ and Teodorico Alves Sobrinho ${ }^{2}$ \\ 1 Department of Hydraulics and Sanitation, São Carlos School of Engineering, University of São Paulo, São \\ Carlos, SP 13566-590, Brazil \\ 2 Faculty of Engineering, Architecture and Urbanism, and Geography, Federal University of Mato Grosso do \\ Sul, Campo Grande, MS 79070-900, Brazil; paulo.t.oliveira@ufms.br (P.T.S.d.O.); \\ pedro.zamboni@aluno.ufms.br (P.A.P.Z.); nelson.vieira@aluno.ufms.br (N.O.M.V.); \\ glauber.altrao@ufms.br (G.A.C.); teodorico.alves@ufms.br (T.A.S.) \\ 3 Embrapa Beef Cattle, Campo Grande, MS 79106-550, Brazil; manuel.macedo@embrapa.br (M.C.M.M.); \\ alexandre.araujo@embrapa.br (A.R.d.A.); denise.montagner@embrapa.br (D.B.M.) \\ * Correspondence: julliansone@usp.br; Tel.: +55-67-99925-0212
}

Received: 13 August 2019; Accepted: 24 September 2019; Published: 27 September 2019

\begin{abstract}
Integrating agricultural land uses is a suitable alternative for fostering economic development and improving food security. However, the effects of long-term integrated systems on soil erosion and water infiltration are still poorly understood. Here, we investigate the influence of different agricultural land uses on soil erosion and water infiltration in an Oxisol site located in the Brazilian Cerrado region. The experimental area consisted of continuous grazing under variable stocking rates with regular fertilization (CG-RF), continuous cropping under no-till (CC-NT) and no-till with 4-year subsoiling (CC-SS), rotation of one year cropping and three years livestock in the livestock phase (C1-L3), rotation of four years cropping and four years livestock in the cropping phase $(\mathrm{CL}-4 \mathrm{C})$ and in the livestock phase (CL-4L), and integrated crop-livestock-forestry in the cropping phase (CLF-C) and in the livestock phase (CLF-L). To evaluate water infiltration and soil loss, we used a rainfall simulator with a constant rainfall intensity of $74.9 \pm 3.6 \mathrm{~mm} \mathrm{~h}^{-1}$ in plots of $0.7 \mathrm{~m}^{2}$. We carried out 72 rainfall simulations comprising four repetitions in each treatment under vegetation and bare soil. Stable infiltration rate (SIR) ranged from 45.9 to $74.8 \mathrm{~mm} \mathrm{~h}^{-1}$ and 19.4 to $70.8 \mathrm{~mm} \mathrm{~h}^{-1}$ under vegetation covers and bare soil, respectively. Our findings indicated that SIR values under CLF-C were $60 \%$ greater than under CG-RF. We also found that soil loss rates under CLF-C were 50\% smaller than under CG-RF. The crop-livestock rotation period that presented better results of SIR and soil loss was one year of cropping and three years of livestock (C1-L3). Overall, we noted that SIR and soil loss values under CLF-C are similar to the Cerrado native vegetation. Therefore, our study reveals the opportunity to increase agricultural production, improve food supply, and reduce soil erosion with adequate soil and agricultural management.
\end{abstract}

Keywords: food demand; crop-livestock rotation; agroforestry

\section{Introduction}

The ever-increasing global population's demand for food and energy has generated the intensified use of farm machinery and heavier livestock stocking rates in several regions; for instance, the total net import of staple crops in the world will probably increase by a ratio of 2.2 by 2050 , considering a 
scenario of low population growth [1]. It has led to soil compaction and deterioration in soil physical properties, particularly storage and supply of water [2]. In addition, climate change has challenged the limits of sustainability in agriculture [3], contributing to arable land degradation and increasing food insecurity. Therefore, it is necessary to develop soil management systems that endure severe storms and droughts, allowing food production and environmental protection, as well as increasing production in small areas. Suitable soil is one of the most essential resources determining food security [4], so understanding and mitigating soil erosion are fundamental to soil productivity [5].

Crop residue management and no-till are considered sustainable crop production systems. The use of crop residue began to spread in the United States of America during the 1930s and 1940s, while in Brazil, that practice started in 1969 in the Rio Grande do Sul state and later in the Paraná state in the 1970s [5]. The modern concept of soil and water conservation stems from maintaining soil cover using crop residue, minimizing soil disturbance, and diversifying growing cultures such as agroforestry systems. Concurrently, assessing soil and water losses is paramount for prioritization and formulation of proper land management programs that aim at sustainable development. One of the eight soil and water conservation principles states that long-term research and data collection and availability are key to sustainably managing agricultural lands [6]. However, there have been few studies experimentally addressing water and soil losses in long-term agroforestry systems along with continuous cropping and grazing. The existing studies were carried out under recent agroforestry experiments but they did not analyze environmental aspects integrating the three components (crop-livestock-forestry) [7].

Agroforestry contributes to maximizing the use of available land in an effective manner; moreover, adopting soil and water conservation becomes fundamental in integrating crop, livestock, and forestry. Crop-livestock-forestry integration has provided opportunities to mitigate poverty and improve agricultural productivity in Central and East Africa [3]. Some researchers have argued that sustainable crop yield intensification is balancing competition between land use for agriculture environmental protection [8-10] even though the scarcity of palpable evidence has discouraged some farmers [11]. Additionally, technological improvements encourage expansion in agricultural frontiers and farmers only migrate to intensive agricultural productions when they face land resources scarcity [12].

Cropland area expansion is projected in the 21st century [4], for instance, the new major agricultural frontier located in the Brazilian Cerrado known as Matopiba [13]. This expansion area comprises the states of Maranhão-MA, Tocantins-TO, Piauí-PI, and Bahia-BA (Matopiba), covering about 45 million hectares. Matopiba is responsible for $10 \%$ and $15 \%$ of the Brazilian production of soybean and maize, respectively. In this region, soybean area expanded 83\% from 2005 to 2014 while the increase was $29 \%$ at the national level in the same period [14]. On one hand, cropland area expansion in Matopiba could result in an annual rainfall decrease varying between 8 and $16 \mathrm{~mm}$ due to deforestation [13]. Furthermore, it is estimated that up to 5 million hectares will be degraded globally by soil erosion [3]. On the other hand, agroforestry production is increasing in the Cerrado $[15,16]$, which is a global biodiversity hotspot contributing $43 \%$ of Brazil's surface water outside of the Amazon [17]. Thus, it is of strategic importance to understand the impact of agricultural production on soil erosion rates [18] and water balance [19]. Integrated agricultural production is a feasible option to increase food production during times of irregular rain and reduced pasture availability [20], especially for the Cerrado with dry winter and high temperatures in the summer.

The objective of this study was to investigate the influence of different land uses and soil management systems on soil erosion and water infiltration in an Oxisol site located in the Brazilian Cerrado. Our findings contribute to investigating agroforestry systems along with continuous cropping and grazing, allowing sustainable intensification as an alternative to ensure food security in possible scenarios.

\section{Materials and Methods}

We developed this investigation in the experimental site of the Embrapa, located in Campo Grande, Mato Grosso do Sul (Figure 1). The Embrapa has been maintaining a long-term experiment in 
which crop-livestock integrated systems have been studied for 26 years. The experiment was initially designed to compare agronomic and economic efficiencies of different management systems [21]. Currently, the focus has been on the sustainability of these agricultural land uses to contribute to global food security.
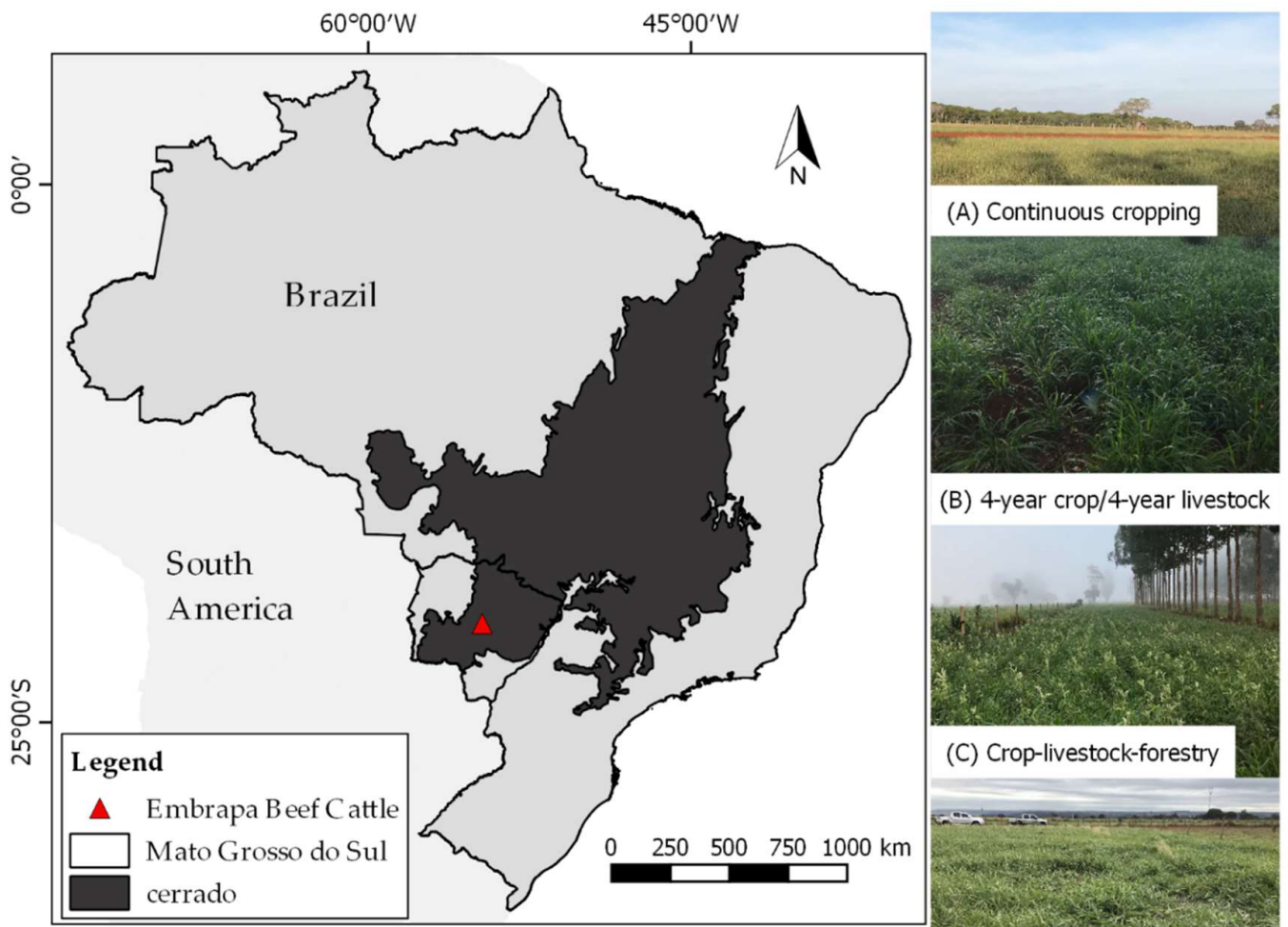

(B) 4-year crop/4-year livestock
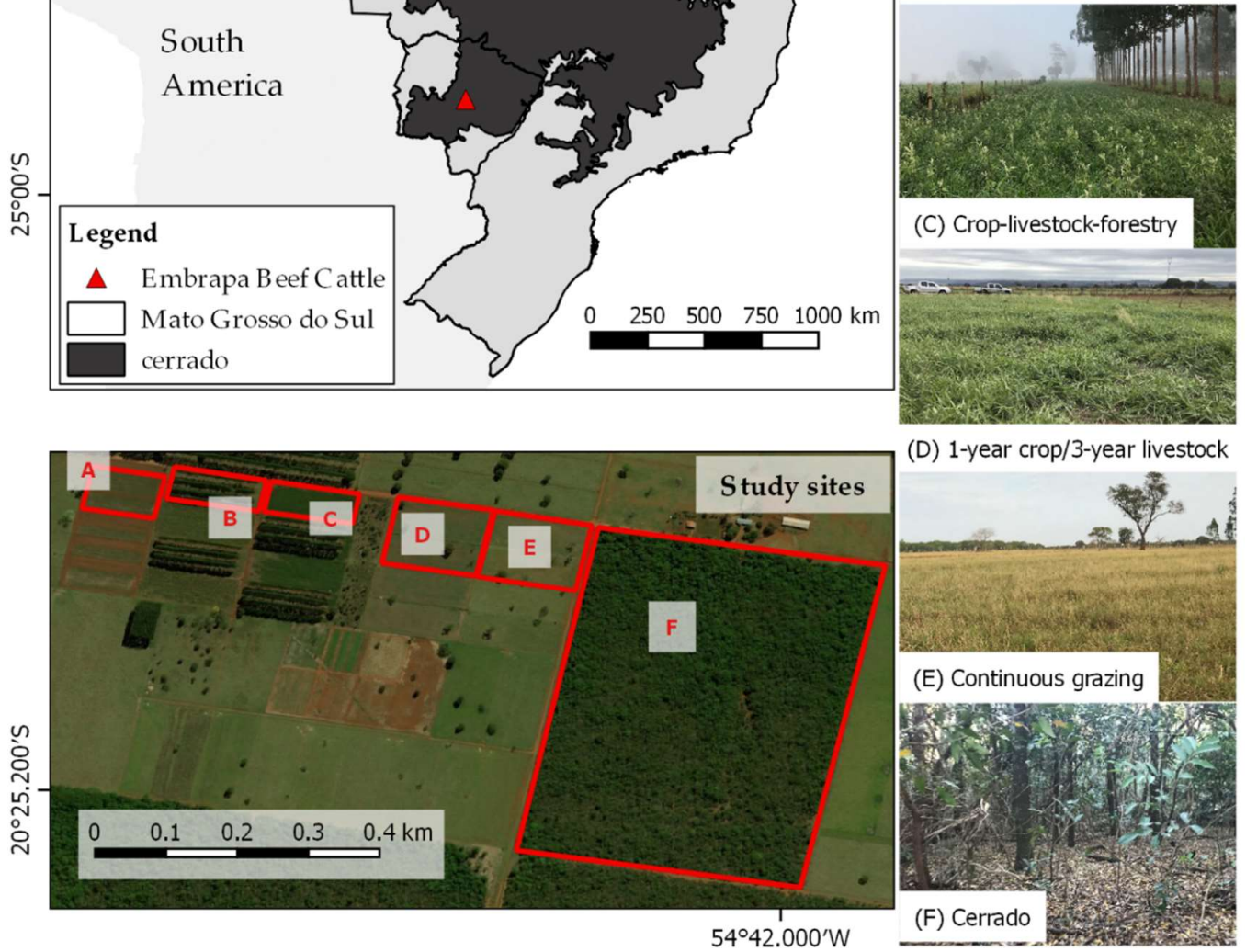

(D) 1-year crop/3-year livestock

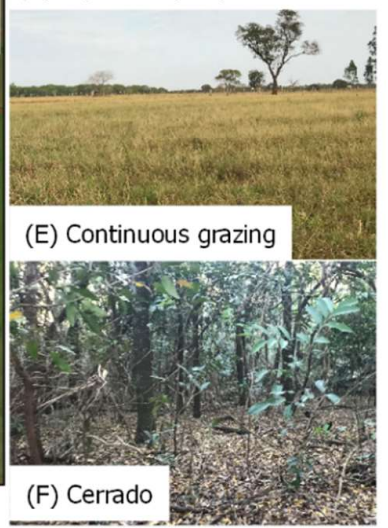

Figure 1. Location of the study sites in the Cerrado biome, where the letters indicate the agricultural uses studied.

According to Köppen, the climate is rainy tropical (Aw) with an average temperature of $22{ }^{\circ} \mathrm{C}$ and average precipitation of $1500 \mathrm{~mm} \mathrm{yr}^{-1}$. The soil is classified as Oxisol ( $35 \%$ of clay at $0-20 \mathrm{~cm} \mathrm{depth),}$ and it is the main soil order in Brazil covering about 32\% of the territory and $45 \%$ of the Brazilian Cerrado [22]. Oxisols have high agricultural potential due to their physical conditions, which allow a suitable soil structure for crop growth. 


\subsection{Treatments and Experimental Design}

The experimental area consisted of 14 ha degraded Brachiaria decumbens pasture, which was restored in 1993 to four agricultural land uses with different management systems as continuous grazing (CG), continuous cropping (CC), and crop-livestock rotation (CL). In 2009, integrated crop-livestock-forestry systems (CLF) were established using Eucalyptus Urograndis (Figure 2). It is an interspecific hybrid combining Eucalyptus grandis (rapid growing) and Eucalyptus urophylla (disease/climate tolerant).

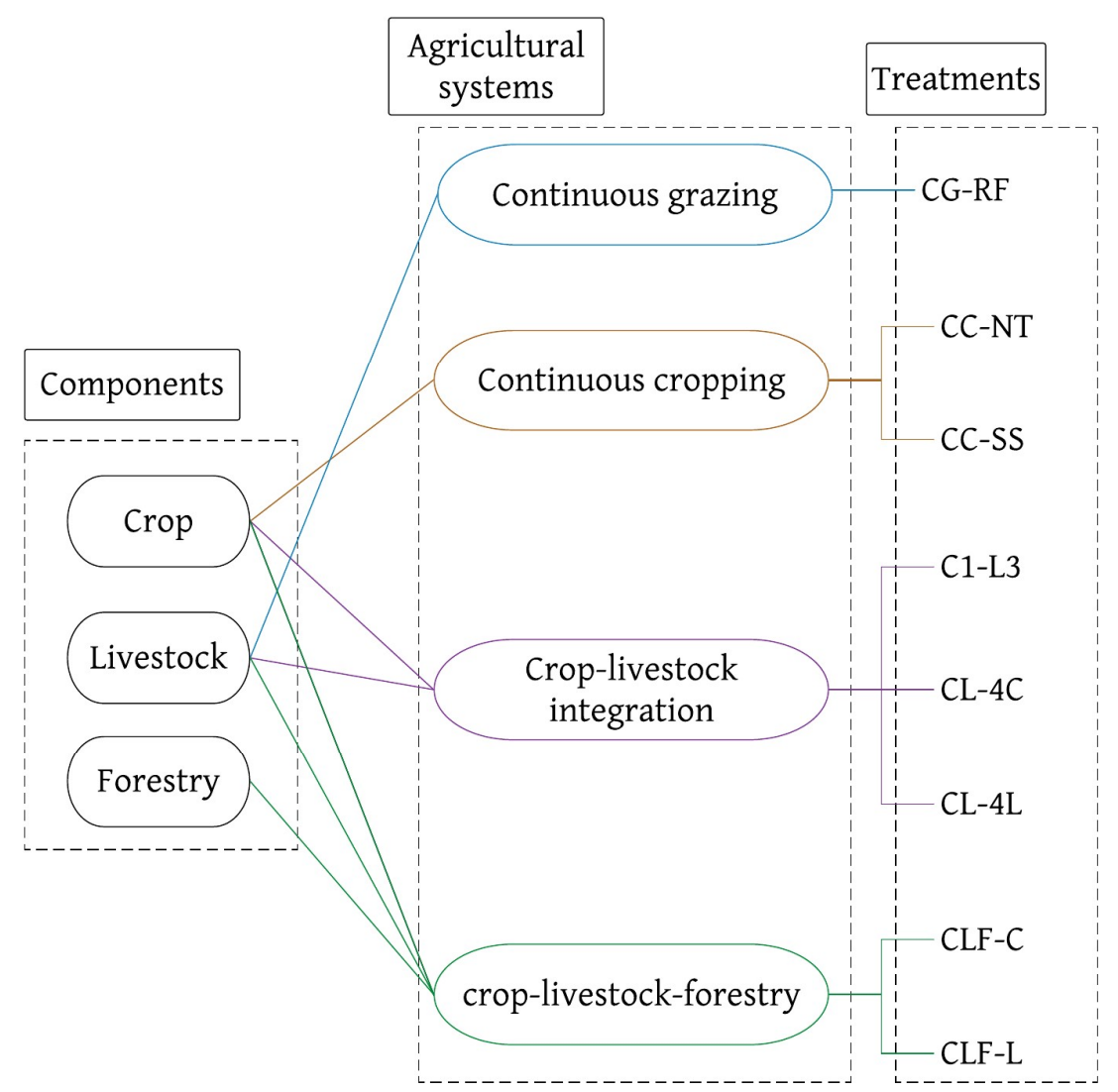

Figure 2. Diagram of the 4 agricultural systems and their respective treatments. Continuous grazing under variable stocking rate with regular fertilization (CG-RF); continuous cropping under no-tillage without subsoiling (CC-NT) and with four-year subsoiling (CC-SS); a rotation of one year cropping and three years livestock (C1-L3); a rotation of four years cropping and four years livestock in the cropping phase (CL-4C) and in the livestock phase (CL-4L); and integrated crop-livestock-forestry in the cropping phase (CLF-C) and in the livestock phase (CLF-L).

Each of the four agricultural systems is composed of treatments with different management practices (Table 1). Also, we considered the Cerrado vegetation (cerrado sensu stricto) as another treatment in our study for comparing native vegetation with the agricultural land uses. We carried out the field experiments at the Embrapa from November 2017 to July 2018. The rainfall simulations were completely randomized with four repetitions within each treatment; after each simulation, we cut the vegetation and performed the test under bare soil (Figure 3). We designed rainfall simulations on vegetation cover and on bare soil to evaluate the effect of both land use and agricultural management along with soil conservation practices on water infiltration and soil loss. Results from bare soil plots give reference values for soil erosion reduction in each treatment. 
Table 1. Four agricultural systems and eight treatments comprising different management practices.

\begin{tabular}{|c|c|c|c|}
\hline $\begin{array}{l}\text { Agricultural } \\
\text { Systems }\end{array}$ & Description & & Treatments \\
\hline $\begin{array}{l}\text { Continuous } \\
\text { Grazing (CG) }\end{array}$ & $\begin{array}{l}\text { Brachiaria decumbens pasture under variable stocking } \\
\text { rate with a minimum of two steers per paddock }(0.70 \\
\text { ha), increasing rate according to forage. }\end{array}$ & CG-RF & $\begin{array}{l}\text { Regular Nitrogen fertilization for } \\
\text { maintenance, according to periodic soil } \\
\text { chemical analysis. We carried out the } \\
\text { measurements in February } 2018 \text { (summer). }\end{array}$ \\
\hline \multirow{2}{*}{$\begin{array}{l}\text { Continuous } \\
\text { Crop (CC) }\end{array}$} & \multirow{2}{*}{$\begin{array}{l}\text { Soybean is cultivated during the summer and } \\
\text { Brachiaria spp during the fall-winter }\end{array}$} & CC-NT & $\begin{array}{l}\text { No-tillage and without subsoiling. We } \\
\text { carried out the measurements in July } \\
2018 \text { (winter). }\end{array}$ \\
\hline & & CC-SS & $\begin{array}{l}\text { No-tillage with subsoiling every four years } \\
\text { The last subsoiling was in November } 2017 . \\
\text { We carried out the measurements in July } \\
2018 \text { (winter). }\end{array}$ \\
\hline \multirow{3}{*}{$\begin{array}{l}\text { Crop-Livestock } \\
\text { rotation }(C L)\end{array}$} & $\begin{array}{l}\text { Rotation of soybean cropping under no-till for one year } \\
\text { and Brachiaria brizantha cv. Piatã pasture under variable } \\
\text { stocking rate with annual fertilization for three years. }\end{array}$ & C1-L3 & $\begin{array}{l}\text { The three-year livestock phase started in } \\
\text { 2018. We carried out the measurements in } \\
\text { August } 2018 \text { (winter). }\end{array}$ \\
\hline & \multirow{2}{*}{$\begin{array}{l}\text { Rotation of soybean cropping under no-till with } \\
\text { Brachiaria spp. and Cajanus cajan cv. BRS Mandarim as } \\
\text { fall-winter crops for four years and Panicum maximum } \\
\text { cv. Massai pasture under continuous grazing and } \\
\text { variable stocking rate for four years. }\end{array}$} & CL-4L & $\begin{array}{l}\text { We carried out the measurements in } \\
\text { April-June } 2018 \text { (fall) during the four-year } \\
\text { livestock phase, which started in } 2018 \text {. }\end{array}$ \\
\hline & & CL-4C & $\begin{array}{l}\text { We carried out the measurements in June } \\
2018 \text { (fall) during the four-year cropping } \\
\text { phase, which started in } 2018 .\end{array}$ \\
\hline \multirow{2}{*}{$\begin{array}{l}\text { Integrated } \\
\text { Crop-Livestock- } \\
\text { Forestry (CLF) }\end{array}$} & \multirow{2}{*}{$\begin{array}{l}\text { Eucalyptus urograndis ( } 28 \times 4 \mathrm{~m} \text { paired-row) is } \\
\text { associated with a crop-livestock rotation system (CL). } \\
\text { The CL management in this treatment is equivalent to } \\
\text { the abovementioned: a rotation of four years cropping } \\
\text { and four years livestock. }\end{array}$} & CLF-L & $\begin{array}{l}\text { The four-year livestock phase started in } \\
\text { 2018. It consists of Panicum maximum cv. } \\
\text { Massai pasture under continuous grazing } \\
\text { and variable stocking rate. We carried out } \\
\text { the measurements in April-June } 2018 \text { (fall). }\end{array}$ \\
\hline & & CLF-C & $\begin{array}{l}\text { The four-year cropping phase started in } \\
\text { 2018. It consists of soybean cropping under } \\
\text { no-till with Brachiaria spp. and Cajanus } \\
\text { cajan cv. BRS Mandarim as fall-winter } \\
\text { crops. We carried out the measurements in } \\
\text { June } 2018 \text { (fall). }\end{array}$ \\
\hline
\end{tabular}

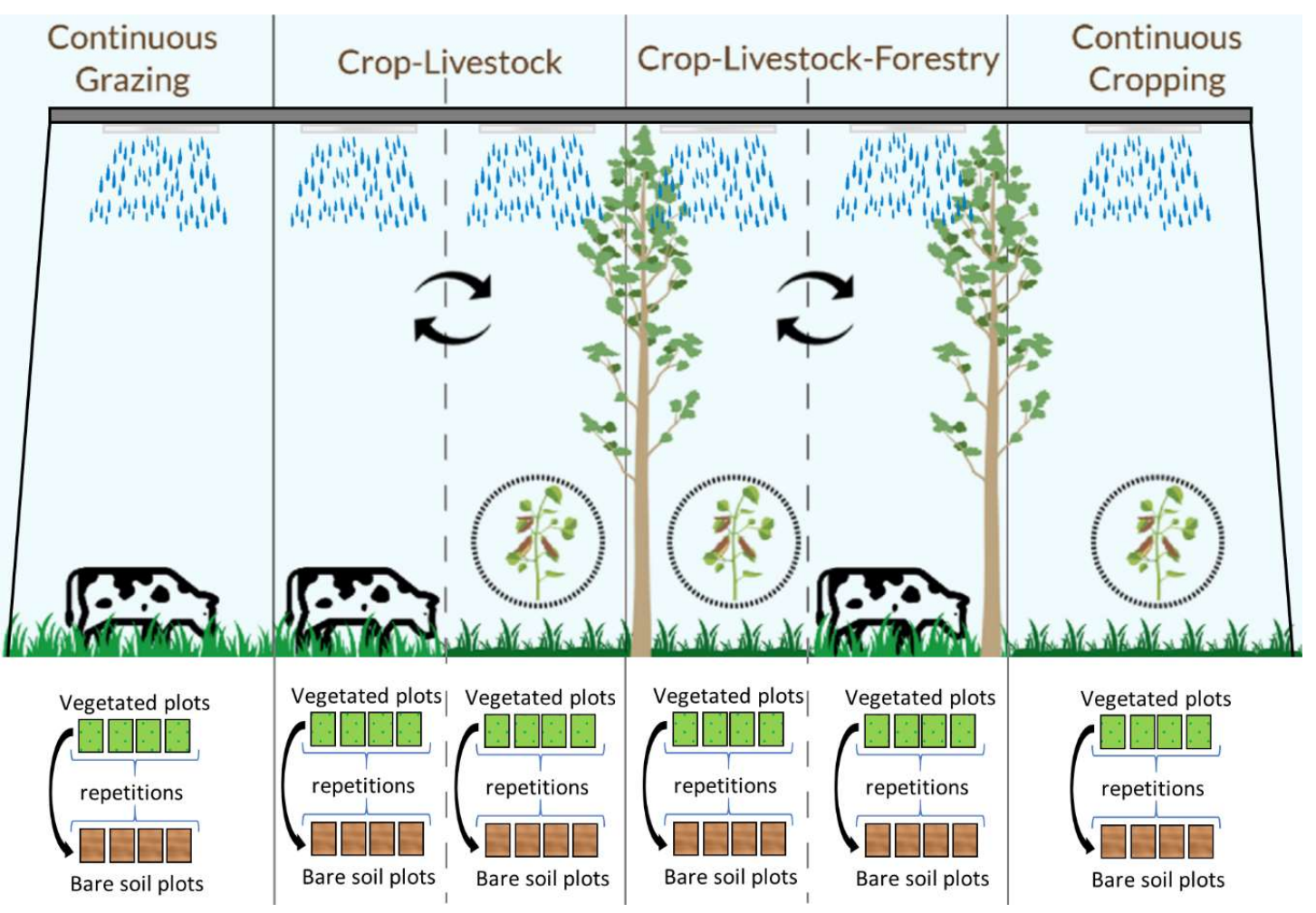

Figure 3. Water infiltration and soil loss tests performed in four agricultural systems with four repetitions for treatment: continuous grazing, crop-livestock integration, crop-livestock-forestry integration. 


\subsection{Data Collection}

We carried out 72 rainfall simulations using a portable rainfall simulator [23]. It was equipped with two parallel Veejet 80.150 flat spray nozzles that provide $2 \mathrm{~mm}$ raindrops at a height of $2.3 \mathrm{~m}$ with a working pressure of $35.6 \mathrm{kPa}$. Additionally, we calibrated the equipment to apply a constant rainfall intensity of $74.9 \pm 3.6 \mathrm{~mm} \mathrm{~h}^{-1}$ for $60 \mathrm{~min}$ after runoff onset [24]. The runoff collecting area was a plot of $0.7 \mathrm{~m}^{2}$ with $2 \mathrm{~mm}$ thick galvanized iron sheets.

During the simulations, the infiltration rate was obtained by the difference between the rainfall intensity and surface runoff measured for one minute every 2 minutes. Additionally, the observed infiltration was fitted to Horton's model $[25,26]$, which has been widely used for estimating water infiltration rate from rainfall simulator data $[27,28]$. The equation's parameters were evaluated by fitting the experimental data using generalized reduced gradient method, a nonlinear regression:

$$
f(t)=f_{c}+\left(f_{0}-f_{c}\right) e^{-\mathrm{k} t}
$$

where $f(t)$ is the estimated instant infiltration rate $\left(\mathrm{mm} \mathrm{h}^{-1}\right) ; t$ is the infiltration time (min); and $f_{0}$ and $f_{c}$ are the observed initial and the stable infiltration rates (SIR) $\left(\mathrm{mm} \mathrm{h}^{-1}\right)$ with a decay constant of $\mathrm{k}$. To verify the error of the model's adjustment, we performed the standard error of the regression (S).

For soil loss, we collected runoff samples every 6 minutes and stored them in one liter containers. The total weight of each container was determined, and the runoff samples (water plus sediment) were oven-dried at $70^{\circ} \mathrm{C}$ for a necessary period to ensure total water evaporation and constant dry mass weight. Thus, soil loss for each simulation was calculated as the total sediment load divided by the plot area.

We performed pre-wetting in every rainfall simulation to ensure uniform humidity [29] at least $12 \mathrm{~h}$ before each test; also, we measured the initial and final humidity in each rainfall simulation test. Slope steepness of the experimental plots ranged from 1.8 to $4.9^{\circ}$ (Table 2); however, it did not affect runoff and sediment concentration in plots up to $1 \mathrm{~m}^{2}$ in size [30] as soil erosion is transport-limited at that plot size. Soil bulk density (BD) values were obtained for each treatment from the Embrapa laboratory.

Table 2. Mean physical properties values recorded for the experimental area located in the Embrapa, Campo Grande, Brazil.

\begin{tabular}{ccccc}
\hline Treatments & $\boldsymbol{\theta}_{\mathbf{i}} \mathbf{( \% )}$ & $\boldsymbol{\theta}_{\mathbf{f}} \mathbf{( \% )}$ & $\mathbf{S}$ (degrees) & BD $\mathbf{( g ~ c m}^{-\mathbf{3}} \mathbf{)}$ \\
\hline CG-RF & 24 & 34 & 3.3 & 1.29 \\
CC-NT & 17 & 29 & 4.9 & 1.28 \\
CC-SS & 19 & 28 & 3.1 & 1.43 \\
C1-L3 & 18 & 24 & 3.9 & 1.27 \\
CL-4C & 15 & 23 & 2.0 & 1.32 \\
CL-4L & 18 & 23 & 1.8 & 1.38 \\
CLF-C & 13 & 23 & 2.0 & 1.34 \\
CLF-L & 12 & 21 & 1.9 & 1.35 \\
Cerrado & 19 & 22 & 3.0 & 0.89
\end{tabular}

Note: $\mathrm{S}$ is slope steepness; $\theta \mathrm{i}$ and $\theta \mathrm{f}$ are initial and final gravimetric soil water content; BD is soil bulk density; CG-RF is continuous grazing under variable stocking rate with regular fertilization; CC-NT is continuous cropping under no-tillage without subsoiling; CC-SS is continuous cropping under no-tillage with four-year subsoiling; C1-L3 is a rotation of one year cropping and three years livestock in the livestock phase; CL-4C is a rotation of four years cropping and four years livestock in the cropping phase; CL-4L is a rotation of four years cropping and four years livestock in the livestock phase; CLF-C is an integration of crop-livestock-forestry in the cropping phase; CLF-L is an integration of crop-livestock-forestry in the livestock phase.

\subsection{Statistical Analysis}

Cluster analysis was performed using Euclidean distance and the hierarchical single linkage method (also known as nearest neighbor) to identify groups of treatments based on water infiltration and soil erosion results. Additionally, we performed Scott-Knott test $(\alpha=0.05)$ to compare the effect of different land uses and soil management on water infiltration and soil erosion. Stable infiltration rate 
(SIR) and soil loss means from each treatment were divided into groups without overlapping by using a probabilistic approach with an asymptotic $\chi 2$ distribution. Both analyses were performed with the statistical and computing environment $\mathrm{R}$ (Scott-Knott package) [31]. Hierarchical tests account for possible statistical dependence since we have limited replication of all treatments.

\section{Results}

We noted a suitable model fit with most errors smaller than the standard deviation of the rainfall intensity applied (Table 3). The highest errors of the regression (S) occurred for SIR smallest values. Figure 4 shows the stable infiltration rate (SIR) and soil loss (SL), respectively in Figure 4A,B, considering vegetation cover. It is shown in the 25th and 75th percentiles, the median with a line, the mean with a rhombus, whiskers indicate the maximum and minimum values. We found the smallest water and soil losses values when croplands replaced livestock lands (CL-4C and CLF-C), except CC-NT and C1-L3 (Figure 4). We performed the rainfall simulations a few months after the transition from pasture phase to the cropping phase, therefore, the grazing management under variable stocking rate indirectly improved water infiltration and decreased soil loss. Conversely, greater water and soil losses were recorded at the treatments that changed from cropping to livestock in the year we carried out the simulations (CL-4L and CLF-L).

Table 3. Horton's equation and soil loss (SL) of each treatment with vegetation cover and on bare soil.

\begin{tabular}{|c|c|c|c|c|c|c|}
\hline Treatments & Horton's Equation & $S$ & $\begin{array}{l}\text { Mean SIR } \\
\left(\mathrm{mm} \mathrm{h}^{-1}\right)\end{array}$ & sd & $\begin{array}{c}\text { Mean SL } \\
\left(\mathrm{g} \mathrm{s}^{-1} \mathrm{~m}^{-2}\right)\end{array}$ & sd \\
\hline \multicolumn{7}{|l|}{ Vegetation cover } \\
\hline Cerrado & $f(t)=71.6+2.5 \times e^{-0.04 t}$ & 2.7 & $71.1 \mathrm{a}$ & 3.5 & $3.3 \times 10^{-4} \mathrm{a}$ & $1.3 \times 10^{-4}$ \\
\hline CG-RF & $f(t)=47.3+18.1 \times e^{-0.14 t}$ & 9.2 & $45.9 \mathrm{~b}$ & 14.0 & $1.1 \times 10^{-3} \mathrm{a}$ & $6.9 \times 10^{-4}$ \\
\hline CC-NT & $f(t)=75.8+5.2 \times e^{-0.17 t}$ & 1.0 & $73.3 \mathrm{a}$ & 0.7 & $4.9 \times 10^{-4} \mathrm{a}$ & $2.8 \times 10^{-4}$ \\
\hline CC-SS & $f(t)=69.0+14.0 \times e^{-0.12 t}$ & 9.8 & $55.8 \mathrm{~b}$ & 12.6 & $2.9 \times 10^{-3} \mathrm{a}$ & $2.1 \times 10^{-3}$ \\
\hline C1-L3 & $f(t)=71.2+7.9 \times e^{-0.21 t}$ & 1.2 & $71.1 \mathrm{a}$ & 1.6 & $4.4 \times 10^{-3} \mathrm{a}$ & $3.1 \times 10^{-5}$ \\
\hline CL- $4 \mathrm{C}$ & $f(t)=72.3+2.1 \times e^{-0.28 t}$ & 0.7 & $72.3 \mathrm{a}$ & 0.9 & $2.7 \times 10^{-4} \mathrm{a}$ & $2.1 \times 10^{-5}$ \\
\hline CL-4L & $f(t)=59.7+14.7 \times e^{-0.22 t}$ & 14.2 & $52.8 \mathrm{~b}$ & 23.4 & $4.7 \times 10^{-3} \mathrm{a}$ & $4.5 \times 10^{-4}$ \\
\hline CLF-C & $f(t)=75.1+5.0 \times e^{-0.21 t}$ & 2.2 & $74.8 \mathrm{a}$ & 2.6 & $5.8 \times 10^{-4} \mathrm{a}$ & $2.2 \times 10^{-4}$ \\
\hline CLF-L & $f(t)=47.3+23.3 \times e^{-0.06 t}$ & 6.4 & $49.0 \mathrm{~b}$ & 7.8 & $7.0 \times 10^{-3} \mathrm{~b}$ & $4.6 \times 10^{-3}$ \\
\hline \multicolumn{7}{|l|}{ Bare soil } \\
\hline Cerrado & $f(t)=69.8+11.1 \times e^{-0.07 t}$ & 3.2 & $69.4 \mathrm{a}$ & 4.1 & $8.4 \times 10^{-4} \mathrm{a}$ & $6.1 \times 10^{-4}$ \\
\hline CG-RF & $f(t)=18.3+48.7 \times e^{-0.14 t}$ & 9.4 & $19.4 \mathrm{~d}$ & 5.8 & $2.0 \times 10^{-2} \mathrm{~b}$ & $5.0 \times 10^{-3}$ \\
\hline CC-NT & $f(t)=60.0+13.1 \times e^{-0.05 t}$ & 3.7 & $62.9 \mathrm{~b}$ & 4.1 & $7.0 \times 10^{-3} \mathrm{a}$ & $3.7 \times 10^{-3}$ \\
\hline CC-SS & $f(t)=41.7+30.7 \times e^{-0.04 t}$ & 6.5 & $36.7 \mathrm{c}$ & 2.9 & $2.5 \times 10^{-2} \mathrm{~b}$ & $1.7 \times 10^{-2}$ \\
\hline C1-L3 & $f(t)=71.0+3.1 \times e^{-0.33 t}$ & 0.5 & $70.8 \mathrm{a}$ & 0.4 & $7.0 \times 10^{-3} \mathrm{a}$ & $8.7 \times 10^{-3}$ \\
\hline CL-4C & $f(t)=53.8+15.5 \times e^{-0.05 t}$ & 9.8 & $53.8 \mathrm{~b}$ & 18.4 & $4.0 \times 10^{-3} \mathrm{a}$ & $2.6 \times 10^{-3}$ \\
\hline CL-4L & $f(t)=33.7+39.9 \times e^{-0.40 t}$ & 11.5 & $32.6 \mathrm{c}$ & 12.8 & $3.1 \times 10^{-2} \mathrm{~b}$ & $1.9 \times 10^{-3}$ \\
\hline CLF-C & $f(t)=56.6+15.3 \times e^{-0.09 t}$ & 9.5 & $56.6 \mathrm{~b}$ & 10.4 & $8.9 \times 10^{-3} \mathrm{a}$ & $9.7 \times 10^{-3}$ \\
\hline CLF-L & $f(t)=29.9+39.2 \times e^{-0.29 t}$ & 7.5 & $29.3 \mathrm{c}$ & 6.6 & $2.4 \times 10^{-2} \mathrm{~b}$ & $1.1 \times 10^{-2}$ \\
\hline
\end{tabular}

Note: Different letters indicate statistical different groups $(\alpha=0.05)$. $S$ is the standard error of the regression and sd is the standard deviation. CC-NT is continuous cropping under no-tillage without subsoiling; CC-SS is continuous cropping under no-tillage with four-year subsoiling; C1-L3 is a rotation of one year cropping and three years livestock in the livestock phase; $\mathrm{CL}-4 \mathrm{C}$ is a rotation of four years cropping and four years livestock in the cropping phase; CL-4L is a rotation of four years cropping and four years livestock in the livestock phase; CLF-C is an integration of crop-livestock-forestry in the cropping phase; CLF-L is an integration of crop-livestock-forestry in the livestock phase.

In terms of SIR considering all treatments under vegetation cover, we observed the best results in CC-NT, C1-L3, CL-4C, and CLF-C; those treatments were similar to the native Cerrado vegetation. On the other hand, SIR in the CG-RF, CC-SS, CL-4L, and CLF-L was lower than that found at the Cerrado vegetation (Table 3). Moreover, soil loss in all the treatments was similar, except for the CLF-L, where we found the highest soil loss values. The levels of similarity are represented using a dendrogram based on cluster analysis and the k-nearest neighbor (Figure 5A). We observed similarity 
among CC-NT, C1-L3, CL-4C, CLF-C, and the Cerrado as well as among CG-RF, CC-SS, and CL-4L. We also noted the highest dissimilarity of CLF-L regarding the other treatments.
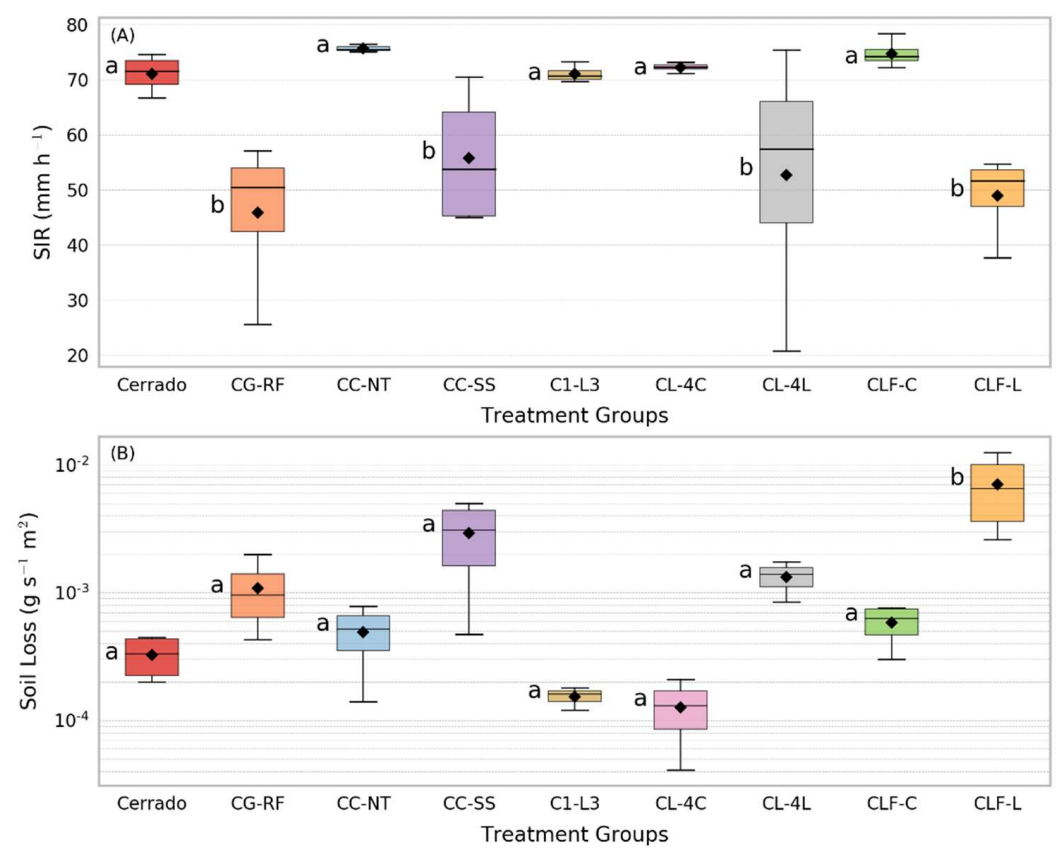

Figure 4. Box plot of stable infiltration rate (SIR) and soil loss (SL), respectively, in (A,B), for each studied treatment. It is shown in the 25th and 75th percentiles, the median with a line, the mean with a rhombus, whiskers indicate the maximum and minimum values. Different letters indicate statistical different groups $(\alpha=0.05)$. CG-RF is continuous grazing under variable stocking rate with regular fertilization; CC-NT is continuous cropping under no-tillage without subsoiling; CC-SS is continuous cropping under no-tillage with four-year subsoiling; C1-L3 is a rotation of one year cropping and three years livestock in the livestock phase; CL-4C is a rotation of four years cropping and four years livestock in the cropping phase; $\mathrm{CL}-4 \mathrm{~L}$ is a rotation of four years cropping and four years livestock in the livestock phase; CLF-C is an integration of crop-livestock-forestry in the cropping phase; CLF-L is an integration of crop-livestock-forestry in the livestock phase.
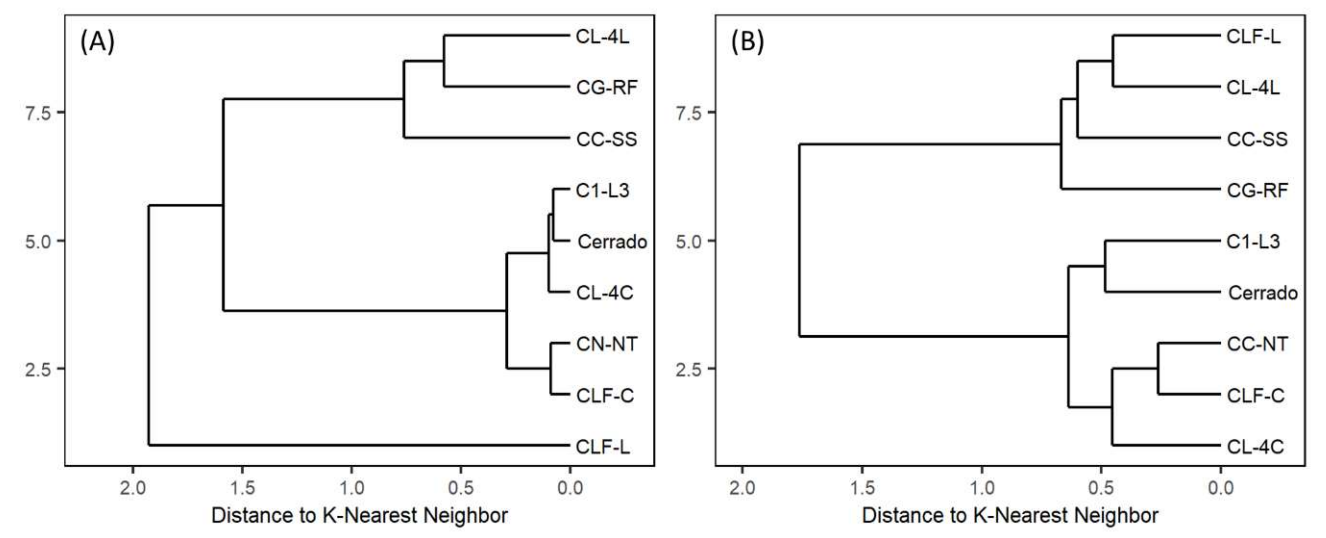

Figure 5. Dendrogram based on k-nearest neighbor considering SIR and soil loss (A) under vegetation cover and (B) on bare soil: continuous grazing under variable stocking rate with regular fertilization (CG-RF), continuous cropping under no-tillage without subsoiling (CC-NT) and with four-year subsoiling (CC-SS), rotation of one year cropping and three years livestock in the livestock phase (C1-L3), rotation of four years cropping and four years livestock in the cropping phase (CL-4C) and in the livestock phase (CL-4L), integration of crop-livestock-forestry in the cropping phase (CLF-C) and in the livestock phase (CLF-L). 
Considering bare soil plots, only C1-L3 presented SIR similar to the Cerrado (Table 3). In terms of soil loss, we observed the lowest values for CC-NT, C1-L3, CL-4C, CLF-C, and the Cerrado. Based on the cluster analysis, the group comprised of the Cerrado, C1-L3, CC-NT, CLF-C, and CL-4C is highly dissimilar to the group of CLF-L, CL-4L, CC-SS, and CG-RF (Figure 5B). High similarity was found between C1-L3 and the Cerrado and among CC-NT, CLF-C, and CL-4C.

Both statistical tests, cluster analysis, and Scott-Knott test presented results that corroborate each other. Hierarchical tests accounts for statistical dependence (Figure 5), while Scott-Knott assumes independence (Figure 4) as it is used with the application of ANOVA. It indicates low possibility of extraneous variable such as geographic proximity or patterns in the soil characteristics affecting our results.

\section{Discussion}

Soil and agricultural management affects water infiltration and soil erosion by modifying soil and vegetation variables. Consequently, we observed different SIR $(\alpha=0.05)$ among some agricultural land uses. How land is managed may change the soil porosity, soil moisture, and organic matter content. Different initial infiltration rates and time intervals required to obtain the constant infiltration are shown in Table 3. These findings are paramount to managing agricultural land uses and controlling soil erosion. We did not find soil bulk density (BD) playing an important role in the infiltration process (Table 2). In fact, water infiltration may be negatively related to BD [32]. We hypothesised that the organic matter content was more related to the results presented in Table 3 than the other soil variables since it also affects soil macro porosity and, consequently, water infiltration [33]. A previous study showed a decrease in organic matter content in land uses changing from pasture to cropland [32]; it corroborates our findings of higher SIR in the treatments that changed to cropping phase from the livestock phase, compared with those that changed from the cropping phase. Additionally, we also noted high SIR and reduced soil loss in the cropping under no-till (CC-NT); however, we ran the rainfall simulations during the fall-winter cropping, with Brachiaria grass as cover crop, and it may have contributed to increasing SIR and reducing soil loss.

The two treatments regarding continuous cropping (CC) showed different SIR results. We found that no-till practice without subsoiling (CC-NT) provided lower runoff and soil loss than no-till practice with subsoiling (CC-SS). Cropping under NT with controlled machinery traffic improved water infiltration into the soil and reduced soil erosion. An improvement in SIR by subsoiling is expected as it reduces soil compaction. A study assessing water infiltration in an Oxisol found higher SIR in treatments using only NT and NT with subsoiling [24]. We carried out the rainfall simulation about six months after the last subsoiling; it may have affected our results, decreasing SIR at CC-SS. We suggest comparing different subsoiling periods and simulation intervals in systems under only NT for better decisions about the management of continuous cropping systems. Soil loss at CC-NT and CC-SS did not statistically differ. Minimizing tillage can improve soil physical properties, particularly by reducing soil bulk density, indirectly improving water infiltration [34], and reducing soil erosion. In addition, crop residue increases SIR [24], becoming key in the crop growth stages [27]. Soil conservation practices are of paramount importance to minimizing the agricultural footprint and increasing productivity.

We expected high SIR and low soil loss values for CG-RF as it received regular fertilization, which provides more herbage mass and great canopy height. It reduces the cattle trampling effect on soil, indirectly contributing to water infiltration into the soil. However, we found lower SIR and similar soil loss for CG-RF compared with the treatments in group a (Figure 4). The Brachiaria decumbens grass may have compromised water infiltration in this treatment since the other treatments in the livestock phase had higher SIR and different grass species. Additionally, a study showed that that grass cover is more effective in reducing soil erosion than surface flow [35], which corroborates our findings. It reveals the importance of pasture renewal to prevent forage growth decline. Integrating crop and livestock provides an opportunity to maintain productivity, increase SIR, and reduce soil loss since we observed an improvement of $60 \%$ in SIR and a reduction of $50 \%$ in soil loss rates. 
The integrated crop-livestock-forestry in the cropping phase (CLF-C) presented SIR and soil loss values similar to the cerrado. Particularly, the crop-livestock and crop-livestock-forestry systems that were leaving the livestock phase and starting the cropping phase showed better performances (Figure 4). Conversely, C1-L3 was the only treatment that migrated from the cropping phase and presented higher SIR compared with the statistical group $\mathrm{b}$. We hypothesize that the cropping period was too short to provide a significant change in soil physical properties improved during the pasture period. Negative effects on soil physical properties may occur depending on the cropping phase length [36]. Therefore, the rotation period in C1-L3 was the most suitable for reducing runoff and soil loss compared with the rotation period in the other crop-livestock and crop-livestock-forestry treatments. Moreover, we noted that CLF-L was the only system that showed different SIR and soil loss considering all treatments. The highest dissimilarity of CLF-L may be due to integrating soybean cropping and Eucalyptus urograndis, since the management practices adopted were identical to the other studied agroforestry systems in the present study. We suggest future research on assessing water infiltration and soil erosion in agricultural production that integrates Eucalyptus spp. plantation with crops, as there are few studies addressing this issue.

Crop-livestock rotation may be a sustainable alternative for increasing productivity as well as introducing grassland and/or perennial forage phases into continuous cropping production as an opportunity for diversifying the land use. This strategy reduces the use of herbicides during the crop phase, mitigating the negative impacts of simplifying land use [37]. Specifically, Brazil has approximately 2.8 million small-scale farms accounting for the country's food production [38]. Therefore, farmers benefit from pasture-crop rotation due to improvements in the soil's physical and chemical properties [39]. Additionally, service crop management needs to become paramount for maximizing crop water supply and improving agroecosystem resilience [40], particularly, with climate change climate affecting the water cycle. Service crops are cover crops grown to provide ecosystem services such as facilitating water infiltration and increasing soil water storage.

\section{Conclusions}

In this study, we assessed the effects of the different agricultural land uses on soil erosion and water infiltration in an Oxisol site located in the Brazilian Cerrado. We carried out 72 rainfall simulations with a rainfall intensity of $74.9 \pm 3.6 \mathrm{~mm} \mathrm{~h}^{-1}$ under the following treatments: continuous grazing under variable stocking rate with regular fertilization (CG-RF), continuous cropping under no-till without subsoiling (CC-NT) and with subsoiling every four years (CC-SS); rotation of one year cropping and three years livestock in the livestock phase (C1-L3), rotation of four years cropping and four years livestock in the cropping phase (CL-4C) and in the livestock phase (CL-4L), integrated crop-livestock-forestry in the cropping phase (CLF-C) and in the livestock phase (CLF-L).

Our findings indicate that with adequate agricultural management, integrated agriculture systems improve water infiltration into the soil and reduce soil erosion, especially rotating crop-livestock with a feasible rotation period for each phase. Crop-livestock and crop-livestock-forestry systems with a four-year rotation period presented the highest SIR and lowest soil loss values after the livestock phase and the beginning of the cropping phase (CLF-C). As those crop-livestock systems that finished the cropping and started the livestock phase (CL-4L and CLF-L) did not perform well, our findings suggest that the best rotation period was one year of cropping and 3 years of pasture (C1-L3) since it considerably increased water infiltration and showed soil loss similar to the cerrado native vegetation, compared with CL-4L and CLF-L. Thereby, pasturelands do not contribute to land degradation if soil conservation practices are adopted as presented in this study. In addition, integrating different agricultural land uses is an opportunity for increasing productivity by intensification and diversifying agricultural production.

We presented here quantitative aspects of variables related to land degradation; nonetheless, a study on water and sediment quality will bring a more complete perspective to the sustainability of integrating different land uses and soil management. Soil modelling would also contribute to a 
mechanistic understanding once large-scale sampling is logistically difficult. Furthermore, larger plots for natural rainfall experiments are the next step to understand the annual variability of runoff and soil erosion; economic factors may also be considered in future research. Long-term research on those land uses under natural rainfall contributes to future studies on modelling soil erosion such as the soil cover and management factor of the universal soil loss equation and its revised versions.

Author Contributions: Conceptualization, J.S.S. and P.T.S.d.O.; methodology, J.S.S., P.T.S.d.O., and T.A.S.; validation, J.S.S. and P.T.S.d.O.; formal analysis, J.S.S., P.T.S.d.O., A.R.d.A., and D.B.M.; investigation, J.S.S.; resources, P.T.S.d.O., T.A.S., M.C.M.M., A.R.d.A., and D.B.M.; data curation, J.S.S., P.A.P.Z., N.O.M.V., and G.A.C.; writing — original draft preparation, J.S.S.; writing—review and editing, P.T.S.d.O., A.R.d.A., and D.B.M.; visualization, J.S.S.; supervision, P.T.S.d.O. and T.A.S; project administration, P.T.S.d.O. and T.A.S.; funding acquisition, P.T.S.d.O., T.A.S., A.R.d.A. and D.B.M.

Funding: This research was funded by the Ministry of Science, Technology, Innovation and CommunicationMCTIC and National Council for Scientific and Technological Development-CNPq (grants 441289/2017-7 and 306830/2017-5) and Coordenação de Aperfeiçoamento de Pessoal de Nível Superior-Brazil—CAPES (Finance Code 001 and Capes Print).

Acknowledgments: The authors also acknowledge the Embrapa Beef Cattle, Campo Grande-MS Brazil, for the partnership and for providing us with the experimental area and the opportunity to carry out our research.

Conflicts of Interest: The authors declare no conflict of interest.

\section{References}

1. Chouchane, H.; Krol, M.S.; Hoekstra, A.Y. Expected increase in staple crop imports in water-scarce countries in 2050. Water Res. X 2018, 1, 100001. [CrossRef] [PubMed]

2. Hamza, M.A.; Anderson, W.K. Soil compaction in cropping systems. Soil Tillage Res. 2005, 82, 121-145. [CrossRef]

3. Premanandh, J. Factors affecting food security and contribution of modern technologies in food sustainability. J. Sci. Food Agric. 2011, 91, 2707-2714. [CrossRef]

4. De Vrese, P.; Stacke, T.; Hagemann, S. Exploring the biogeophysical limits of global food production under different climate change scenarios. Earth Syst. Dyn. 2018, 9, 393-412. [CrossRef]

5. Kassam, A.; Derpsch, R.; Friedrich, T. Global achievements in soil and water conservation: The case of Conservation Agriculture. Int. Soil Water Conserv. Res. 2014, 2, 5-13. [CrossRef]

6. Manale, A.; Sharpley, A.; DeLong, C.; Speidel, D.; Gantzer, C.; Peterson, J.; Martin, R.; Lindahl, C.; Adusumilli, N. Principles and policies for soil and water conservation. J. Soil Water Conserv. 2018, 73, 96-99. [CrossRef]

7. Ribeiro, S.C.; Chaves, H.M.L.; Jacovine, L.A.G.; Silva, M.L. Estimativa do abatimento de erosão aportado por um sistema agrossilvipastoril e sua contribuição econômica. Rev. Árvore 2007, 31, 285-293. [CrossRef]

8. Pretty, J.; Bharucha, Z.P. Sustainable intensification in agricultural systems. Ann. Bot. 2014, 114, 1571-1596. [CrossRef]

9. Tanentzap, A.J.; Lamb, A.; Walker, S.; Farmer, A. Resolving Conflicts between Agriculture and the Natural Environment. PLoS Biol. 2015, 13, e1002242. [CrossRef]

10. Yu, J.; Wu, J. The Sustainability of Agricultural Development in China: The Agriculture-Environment Nexus. Sustainability 2018, 10, 1776. [CrossRef]

11. Jose, S. Agroforestry for ecosystem services and environmental benefits: An overview. Agrofor. Syst. 2009, 76, 1-10. [CrossRef]

12. Barretto, A.G.O.P.; Berndes, G.; Sparovek, G.; Wirsenius, S. Agricultural intensification in Brazil and its effects on land-use patterns: An analysis of the 1975-2006 period. Glob. Chang. Biol. 2013, 19, 1804-1815. [CrossRef]

13. Spera, S.A.; Galford, G.L.; Coe, M.T.; Macedo, M.N.; Mustard, J.F. Land-use change affects water recycling in Brazil's last agricultural frontier. Glob. Chang. Biol. 2016, 22, 3405-3413. [CrossRef]

14. Gomes, L.; Simões, S.; Dalla Nora, E.; de Sousa-Neto, E.; Forti, M.; Ometto, J. Agricultural Expansion in the Brazilian Cerrado: Increased Soil and Nutrient Losses and Decreased Agricultural Productivity. Land 2019, 8, 12. [CrossRef] 
15. Vilela, L.; Martha Junior, G.B.; Macedo, M.C.M.; Marchão, R.L.; Guimarães Júnior, R.; Pulrolnik, K.; Maciel, G.A. Sistemas de integração lavoura-pecuária na região do Cerrado. Pesqui. Agropecuária Bras. 2011, 46, 1127-1138. [CrossRef]

16. Rieger, F.A.; Zolin, C.A.; Paulino, J.; Souza, A.P.; Matos, E.d.S.; de Souza Magalhães, C.A.; Farias Neto, A.L. Water Erosion on an Oxisol under Integrated Crop-Forest Systems in a Transitional Area between the Amazon and Cerrado Biomes; Revista Brasileira de Ciência do Solo: Viçosa, Brazil, 2016; Volume 40, pp. 1-12.

17. Strassburg, B.B.N.; Brooks, T.; Feltran-Barbieri, R.; Iribarrem, A.; Crouzeilles, R.; Loyola, R.; Latawiec, A.E.; Oliveira Filho, F.J.B.; Scaramuzza, C.A.d.M.; Scarano, F.R.; et al. Moment of truth for the Cerrado hotspot. Nat. Ecol. Evol. 2017, 1, 0099. [CrossRef]

18. Oliveira, P.T.S.; Nearing, M.A.; Wendland, E. Orders of magnitude increase in soil erosion associated with land use change from native to cultivated vegetation in a Brazilian savannah environment. Earth Surf. Process. Landf. 2015, 40, 1524-1532. [CrossRef]

19. Oliveira, P.T.S.; Nearing, M.A.; Moran, M.S.; Goodrich, D.C.; Wendland, E.; Gupta, H.V. Trends in water balance components across the Brazilian Cerrado. Water Resour. Res. 2014, 50, 7100-7114. [CrossRef]

20. Moraes, A.; Carvalho, P.C.F.; Crusciol, C.A.C.; Lang, C.R.; Pariz, C.M.; Deiss, L.; Sulc, R.M. Integrated Crop-Livestock Systems as a Solution Facing the Destruction of Pampa and Cerrado Biomes in South America by Intensive Monoculture Systems. In Agroecosystem Diversity; Elsevier: Amsterdam, The Netherlands, 2019; pp. 257-273.

21. Macedo, M.C.M. Integração lavoura e pecuária: O estado da arte e inovações tecnológicas. Rev. Bras. Zootec. 2009, 38, 133-146. [CrossRef]

22. Santos, H.G.; Carvalho-Júnior, W.; Dart, R.O.; Áglio, M.L.D.; Sousa, J.S.; Pares, J.G.; Fontana, A.; Martins, A.L.S.; Oliveira, A.P.O. O novo mapa de solos do Brasil: Legenda atualizada, 1st ed.; Embrapa Solos: Rio de Janeiro, Brazil, 2011.

23. Alves Sobrinho, T.; Gómez-Macpherson, H.; Gómez, J.A. A portable integrated rainfall and overland flow simulator. Soil Use Manag. 2008, 24, 163-170. [CrossRef]

24. Panachuki, E.; Bertol, I.; Sobrinho, T.A.; Oliveira, P.T.S.; Rodrigues, D.B.B. Perdas de solo e de água e infiltração de água em latossolo vermelho sob sistemas de manejo. Rev. Bras. Cienc. do Solo 2011, 35, 1777-1785. [CrossRef]

25. Horton, R.E. The Role of infiltration in the hydrologic cycle. Trans. Am. Geophys. Union 1933, 14, 446-460. [CrossRef]

26. Horton, R.E. Analysis of runoff-plat experiments with varying infiltration-capacity. Trans. Am. Geophys. Union 1939, 20, 693-711. [CrossRef]

27. Almeida, W.S.; Panachuki, E.; Oliveira, P.T.S.; Silva Menezes, R.; Sobrinho, T.A.; Carvalho, D.F. Effect of soil tillage and vegetal cover on soil water infiltration. Soil Tillage Res. 2018, 175, 130-138. [CrossRef]

28. Assouline, S. Infiltration into soils: Conceptual approaches and solutions. Water Resour. Res. 2013, 49, 1755-1772. [CrossRef]

29. Cogo, N.P.; Moldenhauer, W.C.; Foster, G.R. Soil loss reductions from conservation tillage practices. Soil Sci. Soc. Am. J. 1984, 48, 368-373. [CrossRef]

30. Chaplot, V.; Le Bissonnais, Y. Field measurements of interrill erosion under different slopes and plot sizes. Earth Surf. Process. Landf. 2000, 25, 145-153. [CrossRef]

31. Jelihovschi, E.; Faria, J.C.; Allaman, I.B. ScottKnott: A Package for Performing the Scott-Knott Clustering Algorithm in R. TEMA 2014, 15, 3-17. [CrossRef]

32. Sun, D.; Yang, H.; Guan, D.; Yang, M.; Wu, J.; Yuan, F.; Jin, C.; Wang, A.; Zhang, Y. The effects of land use change on soil infiltration capacity in China: A meta-analysis. Sci. Total Environ. 2018, 626, 1394-1401. [CrossRef]

33. Tisdall, J.M.; Oades, J.M. Organic matter and water-stable aggregates in soils. J. Soil Sci. 1982, 33, $141-163$. [CrossRef]

34. Gao, L.; Wang, B.; Li, S.; Wu, H.; Wu, X.; Liang, G.; Gong, D.; Zhang, X.; Cai, D.; Degré, A. Soil wet aggregate distribution and pore size distribution under different tillage systems after 16 years in the Loess Plateau of China. Catena 2019, 173, 38-47. [CrossRef]

35. Li, C.; Pan, C. The relative importance of different grass components in controlling runoff and erosion on a hillslope under simulated rainfall. J. Hydrol. 2018, 558, 90-103. [CrossRef] 
36. Ernst, O.R.; Dogliotti, S.; Cadenazzi, M.; Kemanian, A.R. Shifting crop-pasture rotations to no-till annual cropping reduces soil quality and wheat yield. Field Crops Res. 2018, 217, 180-187. [CrossRef]

37. Kronberg, S.L.; Ryschawy, J. Negative Impacts on the Environment and People From Simplification of Crop and Livestock Production. In Agroecosystem Diversity; Elsevier: Amsterdam, The Netherlands, 2019; pp. 75-90. ISBN 9780128110508.

38. IFAD. Annual Report 2012; IFAD: Rome, Italy, 2012; pp. 1-60.

39. Salton, J.C.; Mercante, F.M.; Tomazi, M.; Zanatta, J.A.; Concenç, O.A.G.; Silva, W.M.; Retore, M. Integrated crop-livestock system in tropical Brazil: Toward a sustainable production system. Ecosyst. Environ. 2014, 190, 70-79. [CrossRef]

40. Ogilvie, C.M.; Deen, W.; Martin, R.C. Service crop management to maximize crop water supply and improve agroecosystem resilience: A review. J. Soil Water Conserv. 2019, 74, 389-404. [CrossRef]

(C) 2019 by the authors. Licensee MDPI, Basel, Switzerland. This article is an open access article distributed under the terms and conditions of the Creative Commons Attribution (CC BY) license (http://creativecommons.org/licenses/by/4.0/). 